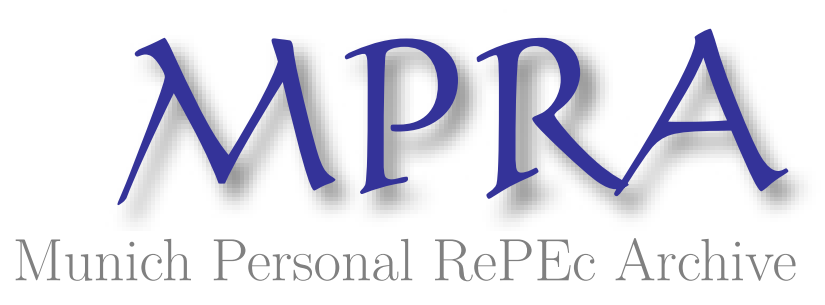

\title{
Monopoly Capital and Innovation: An Exploratory Assessment of RD Effectiveness
}

Lambert, Thomas

Universiety of Louisville

13 October 2018

Online at https://mpra.ub.uni-muenchen.de/89503/

MPRA Paper No. 89503, posted 19 Oct 2018 06:27 UTC 


\title{
Monopoly Capital and Innovation: An Exploratory Assessment of R\&D Effectiveness
}

\author{
Thomas E. Lambert \\ Economics Department, University of Louisville \\ Louisville, Kentucky \\ Thomas.Lambert@Louisville.edu \\ 502-852-7838
}

\begin{abstract}
This research note performs some limited empirical assessments of the Baran and Sweezy (1966) contention that most research and development (R\&D) efforts in the US are "wasted" at the macroeconomic level in that as R\&D succeeds by absorbing a little of the excess economic surplus generated by a capitalist system, it still fails to generate a lot of innovation of a transformative nature. At an aggregate level, greater R\&D efforts are correlated with higher worker productivity and standards of living, which is to be expected according to mainstream economic theory and literature. Yet, R\&D efforts regarding job creation, new firm creation, and net business investment show either mixed results or even negative connections. There is some preliminary empirical support in this paper for many aspects of the Baran and Sweezy point of view on $R \& D$, and these findings also hint that $R \& D$ is used in a monopoly capital system to further monopolization. The findings of this note also may help to explain how productivity gains and innovation over the last few decades may not be benefitting the typical worker or the creation of small businesses as well.
\end{abstract}

Keywords: big business, corporations, entrepreneurship, innovation, monopoly capital, research and development

JEL Codes: B51, L26, O40

October 2018 


\section{Introduction}

In their classic book Monopoly Capital: An Essay on the American Economic and Social Order (1966), Paul A. Baran and Paul M. Sweezy argued that a capitalist economic system chronically suffers from a tendency to stagnate because not enough capitalist profits and earnings (also part of an "economic surplus") cannot be invested rapidly and productively enough in order to keep the system growing with full potential output and employment. That is, there exists "excess surplus" which is not always re-invested. The authors outlined some ways in which this surplus could be absorbed in order to help the economic system avoid stagnation, even though the investment mechanisms or conduits for excess surplus could be considered "wasteful" or unproductive from a societal point of view. These ways or methods included increased defense spending, some civilian government spending (e.g., welfare), corporate spending on advertising, promotions and product differentiation, foreign investment, and research and development, especially corporate research and development (R\&D). ${ }^{1}$

The notion that most R\&D efforts are wasteful would probably strike most mainstream economists and proponents of innovation as outrageous, unfounded and absurd. ${ }^{2}$ Baran and Sweezy would also probably claim that much government R\&D is wasteful since a lot of government-initiated $R \& D$ relates to defense spending. Yet those who believe that $R \& D$ efforts lead to greater innovation, greater worker productivity, and better standards of living claim that R\&D is necessary for economic growth and development. The role that innovation, and along with it the often-parallel concept of entrepreneurship, plays in keeping a capitalist economy

\footnotetext{
${ }^{1}$ Lambert and Kown (2015) argue that nations with higher levels of these forms of surplus absorption usually display high levels of economic inefficiency.

${ }^{2}$ Viki (2016) cites research by a consulting firm that shows no relationship between a firm's level of R\&D spending and its financial performance.
} 
dynamic and growing has been a dominant and persistent theme in most of the economics literature at least since Adam Smith's Wealth of Nations (1776). These were themes especially studied by and written about by the economist Joseph A. Schumpeter $(1942,1983)$, whom Sweezy knew as a friend and sometimes debated in person and in writings on capitalist innovation (Samuelson 1969 and 1972, Foster 1999 and 2011).

Schumpeter's writings on innovation and entrepreneurship have received a great deal of attention over the decades (Schumpeter 1942 and 1983, Blaug 1997 pp. 445-446). As with mainstream economics, Schumpeter once believed that the role of the small entrepreneur was crucial in bringing about innovation, new jobs, and rising standards of living. Additionally, the entrepreneur was also seen as an antidote to large business concentration in that established industries are sometimes usurped by upstart business and new technologies that replace older businesses and technology. According to Schumpeter, the process of "creative destruction" is one in which older industries are replaced by newer ones thanks to the decline of the older industries and their products and the rise of new products due to entrepreneurship (Schumpeter 1983). Newer industries, however, eventually become mature ones, and their products and services eventually saturate markets. If innovations appear in clusters, and then after their appearances there is a subsequent period of an innovation "drought", then an economic downturn is likely to occur. These were the findings of Edmonson (2009) as well regarding the performance of the US economy, although he says large organizations play the primary role in innovation. 
However, Schumpeter ${ }^{3}$ began to see large corporations as a source of innovation and rising standards of living. These organizations had the financial and industrial capacity to develop new products, although he also thought that the decline of small business as a source of innovation would eventually cause the middle classes to lose a lot of confidence in the capitalist system since small business and profitable innovation were vehicles of class mobility (Schumpeter 1942, Foster 2011). The observation that larger businesses are more successful at substantive innovation is borne out by more modern writings, some of which believe that R\&D conducted by highly monopolized industries and large firms is a benefit (Kamien and Schwartz 1982, Darby and Zucker 2006) whereas others see it as a cause for alarm and reject a John Kenneth Galbraith (1956) view of beneficial innovation coming from large firms and concentrated markets (Nelson, Peck and Kalachek 1967).

Schumpeter is thought to have had an influence on Paul M. Sweezy's thinking regarding innovation, business cycles and economic growth (Foster 2014, Baran and Sweezy 2017), although Schumpeter thought that firms, whether large or small, pursued innovation with profits as a goal whereas Sweezy thought that profits or surplus, or the accumulation of profits or surplus, came first, and then firms looked for investment outlets through innovation to absorb the surplus (Schumpeter 1942, Sweezy 1942 and 1953, Foster 2011). Romer (2012) in his textbook, assumes in his models the Schumpeterian view. For Schumpeter, economic crises mostly arose due to innovation cycles wherein sometimes not enough new innovations were forthcoming to yield new products and new industries so as to keep an economy growing. For Sweezy economic crises arose from a lack of surplus absorption wherein the number of new innovative

\footnotetext{
${ }^{3}$ Edmonson (2009) also notes this, but also sees governments and large universities as sources of innovation as well.
} 
products and businesses were not enough to absorb all the surplus generated in a capitalist economy, and so growth stagnated as a growing portion of surplus failed to be reinvested. In general, for Schumpeter, innovators and innovation chased after profits, whereas for Sweezy, profits pursued or looked for possible innovation as an investment outlet (Schumpeter 1942, Sweezy 1942 and 1953, Foster 2011). Samuelson $(1969,1972)$ and Foster $(1999,2011)$ have written about a congenial, public debate held at Harvard University during the 1946-47 school year between Schumpeter and Sweezy on their opposing ideas.

Additionally, Baran and Sweezy (1966) use their Table 1 in Chapter 4 to note there does not appear to be that much of a connection between corporate R\&D and outlays on plant and equipment from 1953 to 1962 (pages 107-110), although there does appear to be a connection between these outlays and depreciation allowances. Also, since R\&D is a cost of production rather than a spending item that comes after profits are counted (which would then definitely make $R \& D$ some form of re-investment), one cannot claim that $R \& D$ generates a great amount of net investment. They write:

"Without claiming that these data constitute proof, we nevertheless do believe that they provide strong support for the view that there is little if any correlation between innovation and investment outlets, and thus monopoly capitalism is increasingly able to take care of its investment needs from depreciation allowances." (page 109), and

"Finally, our conclusion is that technological progress is no more likely than population growth to make a significant contribution to solving the problem of surplus absorption." (page 110).

In fact, when the author of this paper expresses the dollar values in their table as percentages of GDP for each respective year, he finds a negative Pearson correlation coefficient of -0.44

between R\&D spending as a percent of GDP and outlays on plant and equipment as a percent of GDP as well as a negative coefficient of -0.30 between depreciation allowances as a percent of GDP and outlays on plant and equipment as a percent of GDP. However, neither coefficient is 
statistically significant, and so R\&D does not seem to make much of an impact on investment, although only ten years of data is analyzed. ${ }^{4}$ Finally, these numbers and analyses do not address variations at the industry level, or, more specifically, do not address the possibility if innovation in one industry stimulates investment in it yet causes disinvestment in other industries which may be non-innovative or have products or technology in decline. Nonetheless, Baran and Sweezy were only concerned with looking at aggregate numbers since their focus is on how innovation affects macroeconomic conditions. Aggregate numbers are also the focus of this paper.

Baran and Sweezy (1966) do not mention explicitly how innovation and R\&D may impact worker productivity, job creation, new business formation, and other possible effects of greater R\&D and new products and/or new innovations. To fill this void, this paper looks at how R\&D efforts may affect other economic outcomes in addition to investment. This paper proceeds as follows. The next section discusses the research methods employed in and results found in this paper. This is followed by a further discussion of the results along with a conclusion and comments on the implications of the research findings.

\section{Methods and Results}

(Insert Tables 1 and 2 around here)

Table 1 shows the descriptive statistics of the variables used in various models. To test whether spending on patents is perhaps "wasted" or ineffective, and over different lengths of

\footnotetext{
${ }^{4}$ When an index of macro level R\&D efforts from 1947 to 2015 is created (see Methods section), the index turns out to be highly correlated $(r=0.87$ ) with depreciation allowances for fixed assets as a percentage of GDP (US Bureau of Economic Analysis 1947 to 2015) and the correlation is statistically significant. This is something which would be expected given Baran and Sweezy's (1966) claim that depreciation expenses by most large corporations could be used to finance their R\&D work (pages 107-109).
} 
time spans, the independent variable R\&D Efforts was created using factor analysis from several highly correlated variables (see Table 2) such as spending on R\&D as a percent of GDP; real R\&D expenditure in billions of dollars per real GDP per capita ${ }^{5}$; utility patents granted to residents per real GDP per capita; design patents granted per real GDP per capita ${ }^{6}$; patents granted to foreign residents per real GDP per capita ${ }^{7}$; and real expenditures per utility patents granted. ${ }^{8}$ Looking at US Patent and Trademark data (USPTO 1963 to 2015 and 1969 to 2015) it appears for utility patents ("inventions") that the ratio of the number of organizational patents (i.e., patents granted to corporations, universities, and governments) to the number of patents granted to individuals has increased from the early 1970s to recent years from around a factor of over 2 to around 6 indicating a greater and greater role played by organizational R\&D. The greatest number of these patents come from corporate R\&D efforts, although Isenberg (2010) and Mazzacuto (2015) has argued that the most impactful innovations have come from governmental $R \& D$ efforts or from private $R \& D$ efforts supported by the government since some high stakes research and innovation need government resources and assistance since development costs are extremely high, perhaps too high even for large corporations. This is also a point of view of institutionalist economics (Galbraith 1956) as well as those subscribing to a

\footnotetext{
${ }^{5}$ Caballero and Jaffe (2002) among others indicate that patent generation should be put on some type of real GDP basis, and so this is done here in this paper. They also note that innovation diffusion occurs rapidly, and therefore create models in which R\&D efforts are quickly realized once a patent is approved.

${ }^{6}$ Since the Baran and Sweezy and Monthly Review School (Foster 2014) tradition holds that most R\&D efforts are wasteful, this variable is included since design patents mostly affect the appearance of product and not its substance. This is "wasteful" in the sense that such design and packaging efforts are part of the sales efforts of large corporations, which is also wasteful. Nonetheless, business entities engage in such practices because it often helps them with product positioning, possible gains in market share and greater sales, so from a corporate point of view, such efforts are not wasteful. The percentage of patents granted that are in this category grew dramatically over the decades that were examined in this paper.

${ }^{7}$ This category of patents also experience growth during the decades examined, and is also included because patents to foreign residents can be and often are utilized and employed in US domestic production efforts. ${ }^{8}$ Over the time period examined, this value grew in size perhaps indicating that R\&D efforts have mostly become the domain of governmental entities, universities, and large corporations which have the wherewithal to conduct R\&D through large and expensive laboratories, testing centers, etc.
} 
monopoly capital point of view (O'Connor 1973, Foster 2014). In this way, the government also helps with surplus absorption.

Table 2 shows a high degree of correlation of these variables with Factor 1, and so the scores of Factor 1 are chosen as the values for the variable R\&D Efforts, which is used to predict the dependent variables listed in Table 3. When necessary and as indicated by Breusch-Godfrey tests for serial correlation, Newey-West standard errors are used and are displayed in Table 3.

(Insert Table 3 around here)

In examining Table 3, the index R\&D Efforts is a statistically predictor of and explains around $93 \%$ of the variation in a real GDP per worker index with a base year of 2012 (US Bureau of Labor Statistics 1947-2015). This supports the writings of neoclassical economists who have written extensively on how innovation is a key to raising worker productivity and standards of living (Griliches 1984, Zachariadis 2003, Romer 2012). Since most of the literature claims that the aggregate effects of patents are almost instantly felt in the marketplace and put into use, ${ }^{9}$ or that innovation, its implementation, and its impact are usually contemporaneous in the aggregate (e.g., Pakes 1985, Caballero and Jaffe 2002, 146-147, Hall, Thoma, and Torirsi 2007, Gurmu and Perez-Sebastian 2008), the values of the R\&D Efforts index are regressed with

\footnotetext{
${ }^{9}$ One exception is the research by Mansfield (1968 and 1971) who showed that the diffusion of new production innovations could be slow in certain non-competitive, industries unless investment in the new innovations were relatively inexpensive and could show large profits quickly. Otherwise, investment in new technologies were often delayed unless the industry was competitive. On the other hand, larger firms did move faster on average than smaller ones in adopting new production innovations (machinery, techniques, etc.). Mansfield also noted that there can be a significant number of lag years between the time something is invented and then put into use, or becomes an innovation. However, Mansfield was not concerned so much about the aggregate impact of patents and R\&D spending as he was with the diffusion of the innovations within and across industries yielded by inventions which had been patented. Even if implemented by only a handful of firms, the company holding the patent sees an immediate benefit in sales of its invention. He also did not look at the invention and diffusion of consumer products which tend to have more immediate impacts in the marketplace than inventions used in production settings.
} 
the real GDP per worker variable without any time lags. This is done with all the variables in Table $3 .^{10}$ For output per worker, Table 3 shows a one unit increase in the index is associated with an increase of 21.83 points in the real output index.

On the other hand, Table 3 indicates that R\&D does not appear to have any connection to gross domestic investment (US Bureau of Economic Analysis 1947-2015), yet it is significantly, moderately, and inversely correlated with net domestic, private business investment (US Bureau of Economic Analysis 1947-2015). A one unit increase in the R\&D Efforts index is associated with a 1.73 percent decline in net domestic business investment. This somewhat supports the Monthly Review (MR) School point of view that although innovation can increase profit margins through increasing worker productivity, in mature industries any increases in output per worker have to be partially offset by increases in unused plant and equipment capacity, or otherwise a glut of products and services are created, which in turn can lead to lower prices, disruptive price competition, and lower profits among oligopolistic competitors (Steindl 1956, Baran and Sweezy 1966, Kalecki 2009. and Foster 2014). ${ }^{11}$ If worker output per hour is increased, then some workers and equipment have to be idled. Profits due to innovation and greater productivity are not fully absorbed thanks to a reduction in some forms of investment, and so surplus absorption is only partially accomplished. Therefore, according to the MR School, it is sometimes not in the interests of big businesses to innovate unless an innovation helps them to better utilize their existing labor, plant and equipment, and sometimes it is in their interests not to adopt innovations which may weaken or reduce the value of their existing plant and equipment or which may fall

\footnotetext{
${ }^{10}$ In testing some models using lags of 5 or 10 years, the results did not differ that much. Results can be furnished upon request by the author.

${ }^{11}$ Veblen (1899), known as an institutionalist economist, claims that most innovation is subordinated to the pecuniary interests of the firm. Regardless of usefulness, financial considerations are more important when it comes to new products, new production techniques, etc.
} 
short of targeted returns on investment (Foster 2014, Chapter 4). ${ }^{12}$ Sometimes new product plans are dropped if the new and innovative products cannot attain a large corporation's target profit rates, such as Pfizer dropping plans to develop and market new drugs for treating Alzheimer's and Parkinson's diseases, even though such drugs would have very high demand.

Unlike the time periods corresponding to the arrival of innovations such as the steam engine, railroads, and the automobile, most of the $20^{\text {th }}$ century saw the ascendancy of oligopolistic industries in which innovation played a lesser role in profitability, and so net domestic investment would be predicted to slow down compared to investment rates of the $19^{\text {th }}$ century (Steindl 1956, Baran and Sweezy 1966, Kalecki 2009, and Foster 2014). It should be noted that two elements of the index, ornamental patents (patents for product and package designs) and patents granted to foreign residents, increased dramatically during this time period, and these patents may not have the same type of investment effects as utility (invention) patents. Finally, some writers have noted the slowdown in net private business investment in recent decades. Some attribute it to the fact that much new business investment has been relatively costless with many intangible assets being employed now compared to other forms of investment made in previous times (Haskel and Westlake 2018), and some have noted that the net impact of much innovation in the last few decades has perhaps destroyed more jobs than created new ones, and this net job destruction has also exacerbated income inequality (Brynjolfsson and McAfee 2014, Josifidis and Supic 2018). These trends would support the monopoly capital view in that,

\footnotetext{
12 In fact, Foster (2014, Chapter 4) asserts that, as Braverman (1974) noted, one of the biggest innovations of the $20^{\text {th }}$ century was the introduction of scientific management into production and office settings, something which boosted labor productivity in addition to physical investments in plant and equipment.
} 
in the drive toward efficiency and greater profitability, much old investment and forms of labor have to be rendered obsolete, which in turn limits surplus absorption.

At the same, as shown in Table 3, R\&D Efforts is significantly and positively correlated with corporate profits after taxes as a percentage of GDP (US Bureau of Economic Analysis 1947-2015) and the performance of the Standard and Poor's Stock Market Index (S\&P Historical Prices by Year 1871-2018). The index is not correlated at all with Fortune 500 profits as a percentage of GDP, however, and is only weakly correlated with overall corporate profits as a percentage of GDP. Yet it does explain about $75 \%$ of the variation in the value of the S\&P Index from 1947 to 2015 . This anomaly can possibly be explained by the fact that although R\&D does not directly increase overall profits (although it may increase product profit margins), it does make innovating firms more attractive to investors, and so the market value of S\&P firms as expressed in the index would be expected to increase as these large firms experienced gains in productivity.

To examine what effects the R\&D Efforts index has on job, entrepreneurship, and small business creation, the next set of dependent variables listed in Table 3 are used. Innovation and the introduction of new products and the creation of new markets play large roles in economic growth and development theory. The pursuit of profit is a primary motivator for inventors and entrepreneurs, and new products and businesses not only serve the needs of an expanding population but more importantly can also serve as a major source of innovation, which in turn is assumed to be a source of rising standards of living (Harrison 2015, Decker, Haltiwangerb, Jarmind, and Miranda 2016). In forming small enterprises which can sometimes later grow into larger ones, entrepreneurs can enhance existing products and markets or create new products, markets, profits, and employment that help to keep an economy dynamic and thriving (US Small 
Business Administration 2012a). ${ }^{13}$ As the businesses and products/services of one generation of entrepreneurs reach a maturity or saturation stage of the product life cycle (Levitt 1965), new businesses are formed every year which in turn should keep an economy expanding. Despite numerous small (and usually less numerous large) business closures every year, there are enough new innovations and inventions, new small businesses and products that survive to help guarantee that a free enterprise or capitalistic economy continues to grow (Romer 1990, Barro and Sala-I-Martin 1995, Jones 2002, Barro and Sala-I-Martin 1995, Haltiwanger, Jarmin, and Miranda 2010, Harrison 2015, Decker, Haltiwangerb, Jarmind, and Miranda 2016). Therefore, within neoclassical or mainstream economic theory, innovation, entrepreneurship and the flourishing of small businesses are two possible ways that a capitalistic economy could avoid future or worse than would be otherwise stagnation and decline. Innovation is often credited with helping small business formation, helping net job creation, enhancing competition by giving small and new entrants into a market a competitive edge, hence making many markets more competitive, and destroying some older and obsolete firms. Perry (2016) notes the amount of churning in the Fortune 500 list from 1955 to 2016 and notes that only a small percentage of firms on the list in 1955 are still on the list in 2016, although many of the firms on the list changed their names or merged with other large firms to create new entities during this time period. The monopoly capital school of thought, however, would point out that the lack of the

\footnotetext{
${ }^{13}$ The US Small Business Administration (SBA) claims that small businesses accounted for around "64\% of the net new jobs created between 1993 and 2011 (or 11.8 million of the 18.5 million net new jobs)" (US Small Business Administration 2012a, page 1). The same source also states that small businesses are far more productive than their larger counterparts in generating patents per employee by a 16 to 1 ratio over a comparable period of time. Additionally, the product life cycle theory (Levitt 1965) states that as new, innovative and successful products are introduced into an economy, the industries and firms that produce the new products initially expand in terms of employment, sales, and household consumption (the introductory and growth stages of the cycle). Later such growth begins to slow until a "maturity" stage of the product life cycle is reached wherein sales, employment, profits and market shares plateau, and the number of competitors within an industry usually shrinks. If a product becomes obsolete or is replaced by a new innovation, the industry may go into decline and possibly disappear from the marketplace.
} 
continued existence of the same large firms is not what is important. Instead, it is the tendency of most markets to tend toward concentration over time, and this is what is harmful to an economy when it comes to surplus absorption (Foster 2014). Evangelista (2018) claims that mainstream economics is overly "optimistic" regarding the relationship among innovation, technology, and economic growth due to the rise of neo-Shumpeterian analysis and literature within economics. Although he considers himself a type of evolutionary economist and not a mainstream one, Nelson (Nelson and Winter 1982) subscribes to a Shumpeterian point of view by claiming that entrepreneurship and innovation are keys to economic growth, although he disagrees with mainstream economists on the sources of entrepreneurship and innovation and values the role of small business over big business in entrepreneurship.

Contrary to mainstream theory, however, Table 3 shows that the index is negatively correlated with net job creation, overall job creation rate, the job creation rate of new firms/births, job creation rate births 1 to 4 employees, establishment exit rate, establishment exit rate of small firms ( 1 to 4 employees), and the establishment exit rate of employers of 1,000 of more employees (US Census Bureau Business Dynamics Statistics 1977 to 2015). All of these associations are also statistically significant at $\alpha<0.05$, and most of the models have moderate adjusted $r$-squared values with the exception of establishment exit rate of firms 10,000 or more employees (only about 9\%).

(Insert Tables 4 and 5 around here)

Table 4 shows the results of random effects, generalized least squares regression when the number of utility patents granted to Fortune 500 companies is used as a dependent variable and is predicted by each Fortune 500 firm's inflation adjusted revenues in millions for each year 
from 1969 to 2005 (Fortune 5001955 to 2005). ${ }^{14}$ In part A of Table 4, the cases are grouped according to year, and in part B they are grouped according to Fortune 500 company. The inflation adjusted revenues variable is a statistically significant predictor of the number of utility (invention) patents in each of the models and is a better predictor than when inflation adjusted profits are used as an independent variable to predict utility patents granted per year per company (see Table 5). Inflation adjusted profits is a statistically significant independent variable but does not explain as much of the variation in utility patents granted as inflation adjusted revenues. This supports the Baran and Sweezy (1966) notion that R\&D efforts mostly come from revenues and costs of operations ${ }^{15}$ rather than from profits, which according to them indicates that some large, corporate firms have created in-house labs and offices to conduct $R \& D$ on an ongoing basis, and that such efforts are more of a way to absorb economic surplus rather than to generate surplus through profits. Recall from the discussion above that many writers have noted that $R \& D$ expenditures on most innovations and the subsequent patenting are fairly contemporaneous in time, and so the regression results shown in Table 4 are not that surprising from that perspective either.

(Insert Tables 6 and 7 around here)

Beginning in 1981, the federal government started granting a tax credit to companies for their research and development efforts (Holtzman 2017, IRS n.d.). Table 6 shows the results of using least squares regression to predict the total number of patents (utility and ornamental)

\footnotetext{
${ }^{14}$ Utility patent data was only available from 1969 and beyond, and easily accessible data from the Fortune 500 sources only went to 2005. To access other years beyond 2005 was problematic and also expensive. It is hoped that 37 years of data should be sufficient.

${ }^{15}$ Inflation adjusted revenues minus inflation adjusted profits is equal to inflation adjusted general costs, and when costs are estimated, the same results are found for using it as an independent variable as using inflation adjust revenues.
} 
granted each year from 1947 to 2015 using the dummy, independent variable of R\&D Tax Credit where 0 is used for the years 1947 to 1980 , and 1 is used for the years 1981 to $2015 .{ }^{16}$ The dummy variables is statistically significant and explains about $61 \%$ of the variation in patents granted per year. From 1981 to 2015, patents saw an increase of 0.0625 per year more patents granted on average. This shows that perhaps tax considerations gave a boost to patent efforts rather than just the pursuit of profits alone. Figure 1 shows that most of the credits for research activities since 1990 have gone to corporations with gross receipts of $\$ 250$ million or more (US Internal Revenue Service 1990 to 2013).

(Insert Figure 1 around here)

\section{Conclusion}

The results of the models displayed in the preliminary analysis by this paper mostly support the monopoly capital point of view that R\&D expenditures and efforts are not that effective, and although not addressed by the monopoly capital school of thought, perhaps R\&D efforts are also destructive when it comes to net business investment, small business formation, job creation, and promoting competition. Outside of boosting productivity, the only other items on which R\&D efforts have a positive impact is on corporate share prices (S\&P Index) and corporate profits, which are to be expected if a firm has a viable research program and the more difficult it is to replicate a firm's innovations due to patenting, according to mainstream economic theory (Pakes 1985, Cockburn and Griliches 1988). Innovation is linked to increases in productivity, a claim touted and supported by neoclassical economics, but the increases in productivity could be benefitting existing and larger firms at the expense of newer and smaller

\footnotetext{
${ }^{16}$ The US Internal Revenue Service only has detailed data on tax credits by industry and business size mostly going back to 2001, although some data goes back to 1990 .
} 
ones, ${ }^{17}$ and so the closure rates of existing firms could be shrinking for this reason as the number of new smaller firms and new market entrants keep declining, although the exit rates for existing smaller firms has declined. Most of all, as R\&D efforts have increased, the exit rates of larger firms have declined as the portion of firms with 500 or more employees has increased. Table 3 shows R\&D efforts to be positively and significantly associated with the portion of firms of large size. This in turn may be causing a decline in competition in many markets. Finally, with fewer new firms entering markets, this could explain a decline in net business investment over time, especially if the number of most existing firms has increased over time, as indicated by Table 3, and these firms are not using all of their capacity. Part of net business investment comes from new businesses opening. Such a situation could also partially explain a slowdown in new job creation.

All of these trends, in turn, points to possible causes of current and future stagnation in the US economy thanks to declining competition, increasing market concentration, less job creation (although perhaps greater job stability for those who work in larger firms), less net business investment, and greater worker productivity which, in a contradictory way, can minimize the need for more workers and at the same time yields greater profits for large corporations. The rise in profits with fewer new investment outlets thanks to fewer new businesses, in turn, exacerbates the problem of surplus absorption. Such are the contradictions of a monopoly capital system.

\footnotetext{
${ }^{17}$ As Table 7 shows, when the productivity Index is used to predict the Percentage of Firms in the US of size 500 or more employees and the Failure Rate of Firms of size 10,000 or more employees, it is a statistically significant predictor with an adjusted $r$-squared value of 0.713 and 0.082 , respectively. Greater productivity is associated with larger average firm size and lower large firm failure rates, all else held constant, over a 39 year period, 1977 to 2015 .
} 


\section{References}

Baran, Paul A. and Paul M. Sweezy. 2017. The Age of Monopoly Capital: Selected Correspondence of Paul A. Baran and Paul M. Sweezy, 1949-1964 . Edited by Nicholas Baran and John Bellamy Foster. New York, NY: Monthly Review Press.

Barro, Robert J. and Xavier Sala-I-Martin. 1995. Economic Growth. New York, NY: McGraw-Hill Publishers.

Blaug, Mark. 1997. Economic Theory in Retrospect. Cambridge, UK: Cambridge University Press.

Braverman, Harry. 1974. Labor and Monopoly Capital: The Degradation of Work in the $20^{\text {th }}$ Century. New York, NY: Monthly Review Press.

Brynjolfsson, Erik and Andrew McAfee. 2014. The Second Machine Age: Work, Progress, and Prosperity in a Time of Brilliant Technologies. New York, NY: W.W. Norton and Company.

Caballero, Ricardo J. and Adam B. Jaffe. 2002. "How High are the Giants' Shoulders: An Empirical Assessment of Knowledge Spillovers and Creative Destruction in a Model of Economic Growth." In Jaffe, Adam B. and Manuel Trajtenberg, Editors, Patents, Citations, and Innovations. Cambridge, MA and London, UK: The MIT Press.

Cockburn, Ian and Zvi Griliches. 1988. "Industry Effects and Appropriability Measures in the Stock Market's Valuation of R\&D and Patents." American Economic Review, 78(2): 419-423.

Darby, Michael R. and Lynne G. Zudker. 2006. "Innovation, Competition, and Welfare Enhancing Monopoly." National Bureau of Economic Research Working Paper Series, Working Paper 12094. http://www.nber.org/papers/w12094. Accessed on October 11, 2018.

Decker, Ryan A., John Haltiwangerb, Ron S. Jarmin, and Javier Miranda. 2016. "Where has all the skewness gone? The decline in high-growth (young) firms in the U.S." European Economic Review, Volume 86, July 2016, Pages 4-23.

Dilts, Elizabeth. 2018. "Pfizer Ends Research for New Alzheimer's, Parkinson's Drugs" Reuters. https://www.reuters.com/article/us-pfizer-alzheimers/pfizer-ends-research-for-newalzheimers-parkinsons-drugs-idUSKBN1EW0TN . Accessed on October 10, 2018.

Edmonson, Nathan. 2009. Technological Foundations of Cyclical Economic Growth: The Case of the United States Economy. New Brunswick, NJ and London, UK: Transaction Publishers.

Evangelista, Rinaldo. 2018. "Technology and Economic Development: The Schumpeterian Legacy." Review of Radical Political Economics, 2018, 50(1): 136-153.

Fortune 500. 1955-2005. FORTUNE 500: A database of 50 years of FORTUNE's list of America's largest corporations.

http://archive.fortune.com/magazines/fortune/fortune500_archive/full/1955/ . Accessed on September 24, 2018. 
Foster, John Bellamy. 1999. "Remarks on Paul Sweezy on the Occasion of His Receipt of the Veblen-Commons Award.” Journal of Economic Issues 33(2): 223-228.

Foster, John Bellamy. 2011. "On the Laws of Capitalism”, Monthly Review, Vol. 63(1), May 1, 2011. https://monthlyreview.org/2011/05/01/on-the-laws-of-capitalism/. Accessed on April 8, 2018.

Foster, John Bellamy. 2014. The Theory of Monopoly Capitalism: An Elaboration of Marxian Political Economy, New Edition. New York, NY: Monthly Review Press.

Galbraith, John K. 1956. American Capitalism: The Concept of Countervailing Power, Revised Edition. Boston, MA: Houghton Mifflin.

Griliches, Zvi (editor). 1984. R\&D, Patents, and Productivity. Chicago, IL: University of Chicago Press.

Gurmu, Shiferaw and Fidel Perez-Sebastian. 2008. "Patents, R\&D, and Lag Effects: Evidence from Flexible Manufacturing Firms." Empirical Economics (November 2008) 35(3): 507-526. https://doi.org/10.1007/s00181-007-0176-8 . Accessed on October 11, 2018.

Hall, Bronwyn H., Grid Thomas and Salvatore Torrisi. 2007. "The Market Value of Patents and R\&D Evidence from European Firms." Academy of Management Proceedings, vol 2007(1), pages 1-6.

Haltiwanger, John, Ron S. Jarmin, and Javier Miranda. 2010. Who Creates Jobs? Small vs. Large vs. Young. U.S. Bureau of the Census. Center for Economic Studies (CES) 10-17 August, 2010. https://www.census.gov/ces/pdf/CES-WP-02-17.pdf . Accessed on April 8, 2018.

Harrison, JD. 2015. "The Decline of American Entrepreneurship — in Five Charts." The Washington Post. February 12, 2015. https://www.washingtonpost.com/news/on-smallbusiness/wp/2015/02/12/the-decline-of-american-entrepreneurship-in-fivecharts/?utm_term=.c7a395fc3ddd . Accessed on April 8, 2018.

Haskel, Jonathan and Stian Westlake. 2018. Capitalism without Capital: The Rise of the Intangible Economy. Princeton, NJ: Princeton University Press.

Holtzman, Yair. 2017. "U.S. Research and Development Tax Credit," The CPA Journal: Voice of the Profession. October 2017. https://www.cpajournal.com/2017/10/30/u-s-researchdevelopment-tax-credit/. Accessed on September 24, 2018.

Isenberg, Daniel J. 2010. "How to Start an Entrepreneurial Revolution." Harvard Business Review. June 2010. https://hbr.org/2010/06/the-big-idea-how-to-start-an-entrepreneurialrevolution . Accessed on October 10, 2018.

Jones, Charles I. 2002. Introduction to Economic Growth, $2^{\text {nd }}$ Edition. New York, NY: WW Norton and Company. 
Josifidis, Kosta and Novica Supic. 2018. "Income Polarization in the US Working Class: An Institutionalist View.” Journal of Economic Issues, 52(2): 498-508.

Kalecki, Michael. 2009. Theory of Economic Dynamics: An Essay on Cyclical and Long-Run Changes in Capitalist Economy, New York, NY: Monthly Review Press.

Kamien, Morton I. and Nancy L. Schwartz. 1982. Market Structure and Innovation. Cambridge, UK: Cambridge University Press.

Lambert, Thomas E. and Edward Kwon. 2015. "Monopoly Capital and Capitalist Inefficiency". International Review of Applied Economics, 29:4, 533-552, DOI:

$\underline{10.1080 / 02692171.2015 .1016409}$. Accessed on September 8, 2018.

Levitt, Theodore. 1965. "Exploit the Product Life Cycle." Harvard Business Review.

November 1965. https://hbr.org/1965/11/exploit-the-product-life-cycle . Accessed on April 9, 2018.

Mansfield, Edwin. 1968a. Industrial Research and Technological Innovation: An Econometric Analysis. New York, NY: W.W. Norton Co.

Mansfield, Edwin. 1968b. The Economics of Technological Change. New York, NY: W.W. Norton Company.

Mansfield, Edwin. 1971. Technological Change: An Introduction to a Vital Area of Modern Economics. New York, NY: W.W. Norton and Company.

Mazzucato, Mariana. 2015. The Entrepreneurial State. New York, NY: Anthem Press.

Nelson, Richard, Merton Peck, and Edward Kalachek. 1967. Technology, Economic Growth and Public Policy. Washington, DC: The Brookings Institution.

Nelson, Richard R. and Sidney G. Winter. 1982. An Evolutionary Theory of Economic Change. Cambridge, MA: The Belknap Press of Harvard University.

O’Connor, James. 1973. Fiscal Crisis of the State. Piscataway, NJ: Transaction Publishers.

Pakes, Ariel, 1985. “On Patents, R\&D, and the Stock Market Rate of Return,” Journal of Political Economy, 93(2): 390-409.

https://EconPapers.repec.org/RePEc:ucp:jpolec:v:93:y:1985:i:2:p:390-409 . Accessed on October 11, 2018.

Perry, Mark J. 2016. "Fortune 500 Firms 1955 v. 2016: Only 12\% Remain, Thanks to the Creative Destruction that Fuels Economic Prosperity"

http://www.aei.org/publication/fortune-500-firms-1955-v-2016-only-12-remain-thanks-to-thecreative-destruction-that-fuels-economic-prosperity/ . Accessed on October 9, 2018. 
Romer, David. 2012. Advanced Macroeconomics, Fourth Edition. New York, NY: McGrawHill Irwin.

Romer, Paul M. 1990. "Endogenous Technological Change” Journal of Political Economy, October 1990, 98(5, part 2): S71-S102.

S\&P Historical Prices by Year. 1871-2018. No author. http://www.multpl.com/s-p-500historical-prices/table/by-year. Accessed on April 9, 2018.

Samuelson, Paul A. 1969. “Memories.” Newsweek 73, no. 22 (June 2, 1969): 84.

Samuelson, Paul A. 1972. Collected Scientific Papers, vol. 3 (Cambridge, Massachusetts: MIT Press, 1972), 710.

Schumpeter, Joseph A. 1942. Capitalism, Socialism, and Democracy. New York: Harper and Brothers Publishers.

Schumpeter, Joseph A. 1983 (1911). The Theory of Economic Development: An Inquiry into Profits, Capital, Credit, Interest, and the Business Cycle. New Brunswick, US and London, UK: Transaction Publishers.

Smith, Adam (1776). An Inquiry into the Nature and Causes of the Wealth of Nations. 1 (1 ed.). London: W. Strahan.

Steindl, Josef. 1976. Maturity and Stagnation in American Capitalism. New York, NY: Monthly Review Press.

Sweezy, Paul M. 1942. The Theory of Capitalist Development: Principles of Marxian Political Economy. New York, NY: Monthly Review Press.

Sweezy, Paul M. 1953. "Schumpeter's Theory of Innovation," in The Present as History: Essays and Reviews on Capitalism and Socialism, pages 274-282. New York, NY: Monthly Review Press.

U.S. Bureau of Economic Analysis. 1947-2015. Corporate Profits After Tax (without IVA and CCAdj) [CP], retrieved from FRED, Federal Reserve Bank of St. Louis; https://fred.stlouisfed.org/series/CP . Accessed on September 16, 2018.

U.S. Bureau of Economic Analysis. 1947 to 2015. Current-Cost Depreciation of Fixed Assets [M1TTOTL1ES000], retrieved from FRED, Federal Reserve Bank of St. Louis; https://fred.stlouisfed.org/series/M1TTOTL1ES000 . Accessed on October 9, 2018.

U.S. Bureau of Economic Analysis. 1947-2015. Net domestic investment: Private: Domestic business W790RC1Q027SBEA], retrieved from FRED, Federal Reserve Bank of St. Louis; https://fred.stlouisfed.org/series/W790RC1Q027SBEA, Accessed on September 16, 2018. 
U.S. Bureau of Economic Analysis. 1947-2015. Gross domestic investment [W170RC1Q027SBEA], retrieved from FRED, Federal Reserve Bank of St. Louis; https://fred.stlouisfed.org/series/W170RC1Q027SBEA, Accessed on September 16, 2018.

U.S. Bureau of Labor Statistics. 1947-2015. Nonfarm Business Sector: Real Output Per Person [PRS85006163], retrieved from FRED, Federal Reserve Bank of St. Louis; https://fred.stlouisfed.org/series/PRS85006163, Accessed on August 31, 2018.

US Census Bureau. 1977 to 2015. Business Dynamics Statistics 1977 to 2015. https://www.census.gov/ces/dataproducts/bds/data.html . Accessed on September 17, 2018.

US Internal Revenue Service. N.D. Current-year Deduction of Research \& Development Expenditures, https://www.irs.gov/businesses/small-businesses-self-employed/current-yeardeduction-of-research-development-expenditures . Accessed on September 24, 2018.

US Internal Revenue Service. 1990 to 2013. SOI Tax Stats - Corporation Research Credit. https://www.irs.gov/statistics/soi-tax-stats-corporation-research-credit . Accessed on October 13, 2018.

US National Science Foundation (NSF). 2007. Survey of Industrial Research and Development,. https://www.nsf.gov/statistics/iris/history_pub.cfm . Accessed on April 9, 2018.

US National Science Foundation (NSF). 2012. National Science Foundation Statistics, 2012. https://www.nsf.gov/statistics/seind12/pdf/c04.pdf . Accessed on April 9, 2018.

US Patent and Trademark Office. No date. Patent Process Overview.

https://www.uspto.gov/patents-getting-started/patent-process-overview . Accessed on April 9, 2018.

U.S. Patent and Trademark Office. 1963 to 2015. Patent Technology Monitoring Team (PTMT). U.S. Patent Statistics Chart. Calendar Years 1963 - 2015.

https://www.uspto.gov/web/offices/ac/ido/oeip/taf/data/us_stat.htm . Accessed on October 9, 2018.

US Patent and Trademark Office. Patent Technology Monitoring Team (PTMT). 1969-2015. EXTENDED YEAR SET - Patenting By Geographic Region (State and Country), Breakout By Organization, Count of 1969 - 2015 Utility Patent Grants, By Calendar Year of Grant. https://www.uspto.gov/web/offices/ac/ido/oeip/taf/stcasga/usa_stcorg.htm . Accessed on October 9, 2018.

US Small Business Administration. 2012a. Frequently Asked Questions. SBA Office of Advocacy. September 2012. https://www.sba.gov/sites/default/files/FAQ Sept 2012.pdf . Accessed on April 8, 2018. 
Veblen, Thorstein. 1899 (1994). The Theory of the Leisure Class. New York, NY: Penguin Books, USA.

Viki, Tendayi. 2016. "Why R\&D Spending Is Not A Measure Of Innovation.” Forbes. August 21, 2016. https://www.forbes.com/sites/tendayiviki/2016/08/21/why-rd-spending-is-not-ameasure-of-innovation/\#5d321c86c77d . Accessed on October 10, 2018.

Zachariadis, Marios. 2003. "R\&D, Innovation, and Technological Progress: A Test of the Schumpeterian Framework without Scale Effects." Canadian Journal of Economics, August, 36(3): 566-586. 
Figure 1

Pct of Total Amt of R\&D Tax Credit Dollars Claimed by Corps. With Revenues \$250 Million or More

90

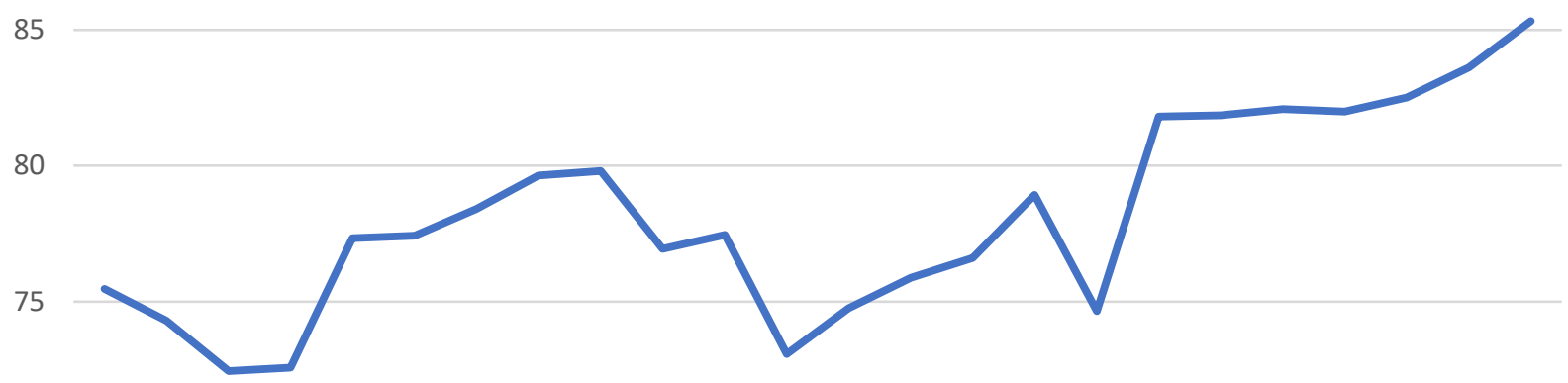

70

65

23 
Table 1--Descriptive Statistics

Variable

R\&D Exp Pct GDP

Real R\&D Exp Bil\$ per Real GDP per Capita

Utility Patents Granted per Real GDP per Capita

Design Patents Granted per Real GDP per Capita

Patents Granted to Foreign Residents per Real GDP per Capita

Real Exp per Utility Patents Granted

Real Output Per Person, Index 2009=100

Current-Cost Depr. Fixed Assets: Private: Nonresidential Pct GDP

Gross private domestic investment Pct GDP

Net Domestic Inv Pct GDP

Corporate Profits Pct GDP

S\&P Index

Net Job Creation

Job Creation Rate

Job Creation Rate Births

Job Creation Rate Births, 1 to 4 Emp

Job Destruction Rate

Establishment Entry Rate

Establishment Entry Rate, 1 to 4 Emp

Establishment Exit Rate

Establishment Exit Rate, 1 to 4 Emp

Establishment Exit Rate, 10,000+ Emp

Pct Firms with 500 or more employees

R\&D Effort $\underline{\text { Obs }}$

69

$\frac{\text { Mean }}{2.45}$
5965939.00
2.84
0.23
1.11

2097291.00

65.49

8.53

17.28

8.26

6.82

529.37

1.98

16.69

6.22

23.05

14.71

12.39

20.37

10.68

18.05

7.74

0.36

0.00
Std. Dev.

$$
0.55
$$

2213730.00

0.84

0.11

0.73

718723.90

23.69

1.46

1.59

2.57

1.72

656.78

2.27

2.25

1.13

3.34

1.85

1.83

2.53

1.21

1.44

1.62

0.03

1.01

$\frac{\text { Min }}{0.98}$
1408955.00
1.43
0.10
0.11

546028.80

29.84

5.53

13.40

1.39

3.81

14.83

$-4.90$

11.50

4.20

16.50

11.10

9.10

15.10

8.60

15.40

4.30

0.30

$-2.13$ $\underline{\text { Max }}$

2.91

9501280.00

5.67

0.50

3.15

3391834.00

110.00

10.68

20.50

12.86

11.24

2789.80

6.60

21.80

9.20

28.50

18.60

17.10

24.40

14.00

21.80

11.70

0.41

2.19 
Table 2--Factor Analysis

Factor loadings (pattern matrix) and unique variances

$\underline{\text { Variable }}$

R\&D Exp Pct GDP

Real R\&D Exp Bil\$ per Real GDP per Capita

Utility Patents Granted per Real GDP per Capita

Design Patents Granted per Real GDP per Capita

Patents Granted to Foreign Residents per Real GDP per Capita

Real Exp per Utility Patents Granted

Scoring

Variable

R\&D Exp. Pct. GDP

Real R\&D Exp Bil\$ per Real GDP per Capita

Utility Patents Granted per Real GDP per Capita

Design Patents Granted per Real GDP per Capita

Patents Granted to Foreign Residents per Real GDP per Capita

Real Exp. per Utility Patents Granted

\begin{tabular}{|c|c|c|c|c|}
\hline Factor1 & Factor2 & Factor3 & Factor4 & Uniqueness \\
\hline 0.80 & 0.51 & -0.29 & 0.09 & 0.02 \\
\hline 0.98 & 0.21 & 0.03 & 0.03 & 0.00 \\
\hline 0.74 & -0.59 & -0.28 & -0.01 & 0.02 \\
\hline 0.71 & -0.51 & 0.36 & 0.11 & 0.09 \\
\hline 0.95 & -0.24 & 0.05 & -0.15 & 0.02 \\
\hline 0.51 & 0.81 & 0.21 & -0.05 & 0.03 \\
\hline
\end{tabular}

coeff. $(\operatorname{method} \quad=\quad$ Bartlett $)$

\begin{tabular}{|c|c|c|c|}
\hline Factor1 & $\underline{\text { Factor2 }}$ & Factor3 & Factor4 \\
\hline 0.34 & 0.41 & -0.87 & 1.91 \\
\hline 0.00 & 0.00 & 0.00 & 0.00 \\
\hline 0.18 & -0.42 & -0.75 & 0.23 \\
\hline 0.26 & -0.27 & 1.08 & 2.49 \\
\hline 0.33 & -0.07 & 0.12 & -3.39 \\
\hline 0.18 & 0.48 & 0.71 & -0.49 \\
\hline
\end{tabular}


Table 3--Time Series Linear Regression Models

Dependent Variables:

Real Output Per Person

Gross private domestic investment

Pct GDP

Net Domestic Inv Pct GDP

Corporate Profits Pct GDP

Fortune 500 Profits Pct GDP

S\&P Index

Net Job Creation

Job Creation Rate

Job Creation Rate Births

Job Creation Rate Births, 1 to 4 Emp

Job Destruction Rate

Establishment Entry Rate

Establishment Entry Rate, 1 to 4

Emp

Establishment Exit Rate

Establishment Exit Rate, 1 to 4 Emp

Establishment Exit Rate, 10,000+

Emp

Pct Firms with 500 or more

employees

$* * \mathrm{p}<0.05$

$* \mathrm{p}<0.10$

Ind. Variable--R\&D Effort

\begin{tabular}{|c|c|c|c|c|}
\hline$\underline{\mathbf{b}}$ & $\underline{\text { Std. Error }}$ & & $\underline{\text { Constant }}$ & Adj. r-squared \\
\hline $21.83^{* *}$ & $(0.72)$ & (NW SE) & 64.22 & 0.93 \\
\hline 0.183 & $(0.19)$ & (SE) & 17.29 & -0.002 \\
\hline$-1.73 * *$ & $(0.28)$ & (NW SE) & 8.37 & 0.46 \\
\hline $0.55^{* *}$ & $(0.25)$ & (NW SE) & 6.82 & 0.09 \\
\hline 0.25 & $(0.24)$ & (NW SE) & 2.27 & 0.012 \\
\hline $467.99 * *$ & (40.12) & (NW SE) & 451.18 & 0.75 \\
\hline$-1.04 * *$ & $(0.47)$ & (SE) & 2.65 & 0.09 \\
\hline$-2.55^{* *}$ & (0.029) & (NW SE) & 18.33 & 0.7 \\
\hline$-1.22^{* *}$ & $(-0.15)$ & (SE) & 7 & 0.64 \\
\hline$-4.04 * *$ & $(0.34)$ & (NW SE) & 25.65 & 0.802 \\
\hline$-1.51^{* *}$ & (0.33) & (SE) & 15.68 & 0.35 \\
\hline$-2.12 * *$ & 0.29 & (SE) & 13.75 & 0.74 \\
\hline$-2.94 * *$ & (0.29) & (NW SE) & 22.26 & 0.74 \\
\hline$-1.26 * *$ & $(0.17)$ & (SE) & 11.49 & 0.59 \\
\hline$-1.18^{* *}$ & $(0.25)$ & (NW SE) & 18.81 & 0.35 \\
\hline$-0.75^{* *}$ & $(0.34)$ & (NW SE) & 8.22 & 0.09 \\
\hline $0.04 * *$ & (0.003) & (NW SE) & 0.34 & 0.79 \\
\hline
\end{tabular}


Table 4--Fortune 500 Revenues and Patents, Panel Data, 1969-2005

\section{Dependent Variable: Number of Patents Granted}

A) Random Effects, GLS Regression*, Observations Grouped by Year

b

(SE)

Inflation Adjusted Revenues in Millions

$0.007 * *$

$(0.0002)$

Constant

r-square within:

0.08

r-square between:

0.39

r-square overall:

0.08

$$
\mathrm{n}=
$$

18483

*Hausman tests showed no difference between fixed and random effects regression.

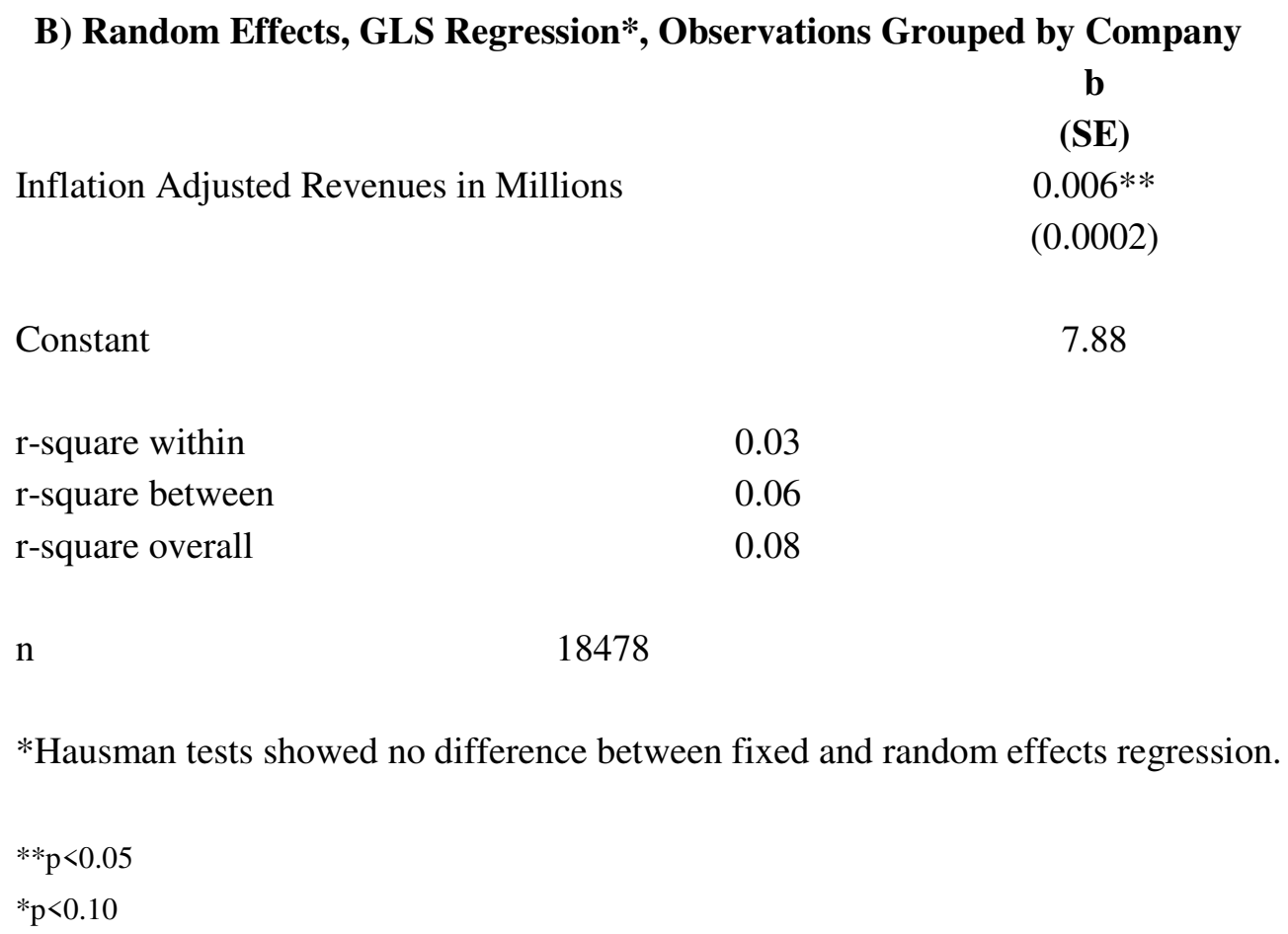


Table 5--Fortune 500 Profits and Patents, Panel Data, 1969-2005

\section{Dependent Variable: Number of Patents Granted}

\section{A) Random Effects, GLS Regression*, Observations Grouped by Year}

b

(SE)

Inflation Adjusted Profits in Millions

$0.043 * *$

(0.002)

Constant

23.99

r-square within:

0.03

r-square between:

0.22

r-square overall:

0.03
$\mathrm{n}=$
18137

*Hausman tests showed no difference between fixed and random effects regression.






\section{Table 6--R\&D Tax Credit and Number of Utility Patents Granted}

Dependent Variable: Number of Utility Patents Granted per Year, 1947-2015

b

(NW SE)

R\&D Tax Credit Dummy Variable

$0.0625^{* *}$

$(0.019)$

Constant

2.52

Adj. r-square:

0.61

$\mathrm{n}=$

69

$* * \mathrm{p}<0.05$

$* \mathrm{p}<0.10$

Table 7--Time Series Linear Regression Models

$\begin{array}{lc}\text { Dependent Variable: Pct. Firms 500+ Employees } & \begin{array}{c}\text { b } \\ \text { (NW Std. } \\ \text { Error) }\end{array} \\ \text { Real Output Per Person Index, } 2009=100 & \\ \text { Constant } & 0.00154^{* *} \\ \text { Adjusted r-squared } & (0.0002) \\ \mathrm{n} & 0.237 \\ \end{array}$

Dependent Variable: Exit Rates Firms 1000+ Employees

Real Output Per Person Index, 2009=100 $\quad-0.03 * *$

$\begin{array}{ll}\text { Constant } & 10.18\end{array}$ 
Adjusted r-squared

0.082

$\mathrm{n}$

$* * p<0.05$

${ }^{*} \mathrm{p}<0.10$ 